\title{
PAUL, THE DEVIL AND 'UNBELIEF' \\ IN ISRAEL
}

\author{
(WITH PARTiCUlar REFERENCE TO \\ 2 CORINTHIANS 3-4 AND ROMANS 9-11)
}

Mohan Uddin

\begin{abstract}
Summary
The theme of this article is a consideration of Paul's theological understanding of the underlying causes of Israel's 'unbelief' with reference to the message of his gospel. An examination of 2 Corinthians 3:1-4:6 and Romans 9-11 indicates that Paul attributed the cause(s) of Jewish 'unbelief' not only to God and Israel itself but also to the 'Satan' figure. This raises the question of the coherence of a particular aspect of Paul's theology; in other words, does his thinking about this matter really make sense? The influence of intertestamental Jewish apocalypticism upon Paul as a former Pharisee and then Christian apostle provides a useful (and, arguably, necessary) tool in the task of evaluating the apostle's theological coherence concerning Israel's large-scale (but certainly not total) rejection of his gospel. While the major aim of the article is a consideration of Paul's coherence concerning this issue within his own time-frame, one cannot entirely lose sight of the hermeneutical problem for readers today when faced with this challenging aspect of Paul's outlook.
\end{abstract}

\section{Introduction}

The question of coherence in Paul's thinking is no small issue for New Testament scholars, especially (need one say) for Pauline specialists. A central problematic theme is Paul's understanding of torah and its place in Christian life (is he for, against or perhaps [intentionally] ambivalent?), but other themes in his 'occasional' writings call for examination with respect to coherence. One such theme is his view of Israel, the larger part of which was-at least for him-'unbelieving'. In this article, I focus upon the question of the 
coherence of Paul's views of causal agency behind Jewish refusal of the gospel with reference to his statements in 2 Corinthians 3-4 (in particular 3:14f. and 4:4) and in Romans 9-11 (in particular 11:7-10, 25 ), which must be seen against the background of the wider issue of the apostle's understanding of evil within the context of his Jewish (and now Christian) monotheism. The suitability of Jewish apocalypticism for 'framing' Paul will be examined first and then the significance of Jewish understanding of the 'Satan' figure as an instrument/agent in God's purposes regarding Israel will be discussed. Paul's use of the 'Satan' figure in 2 Corinthians 3:1-4:6 must be considered at this point before we can reflect upon its implications for theological coherence with Romans 9-11 which concerns causality in Jewish 'unbelief'. Finally, I briefly consider some of the hermeneutical problems involved in such an enquiry and ask how, at this distance from Paul's letters, we stand equipped to demonstrate coherence.

\section{The framework of Jewish apocalypticism and Paul}

There are correspondences between aspects of Jewish apocalypticism and Paul's thought. One can see, for example, that certain dualisms characteristic of Jewish apocalypticism are also present in Paul: the opposition between God and his people on the one hand and Satan / Beliar and his agents on the other, and the belief that the present 'evil age' would (in God's time) give way to a much better 'age to come'. Although it is true that Paul never uses the phrase 'age / world to come' in the undisputed letters, there is no doubt that temporal dualism characterises his thinking as a whole, even if distinctively modified in the light of the Christ-event. He can speak quite clearly about this 'present evil age' (Gal. 1:4) and about himself and the Corinthian believers living at 'the end of the ages' $(1$ Cor. 10:11), the latter reference reflecting a motif within Jewish apocalypticism which sees previous history as a series of epochs running a divinely predetermined course, sometimes referred to as the 'periodisation' of history.' His quite frequent references to 'this age [ $\alpha i \omega$ v]' (1 Cor. 1:20; 2:6, 8; 3:18; 2 Cor. 4:4; Rom. 12:2; cf. Gal. 1:4)

1 On 'periodisation', see P. Sacchi, Jewish Apocalyptic and Its History (JSPSS 20; Sheffield: Sheffield Academic Press, 1996 [ET]; orig. pub. Brescia, 1990), 4445, and J.J. Collins, Apocalypticism in the Dead Sea Scrolls (London/New York: Routledge, 1997), 52-56. 


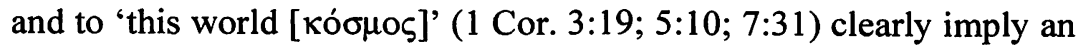
age / world to come, as S.R. Garrett (commenting on 2 Cor. 4:4) and M.C. de Boer also note. ${ }^{2}$ His view of the creation being presently subject to 'futility' but in the future to be 'set free from its bondage to decay' when it will 'obtain the freedom of the glory of the children of God' (Rom. 8:20f.) is redolent of the motif of cosmological renewal in

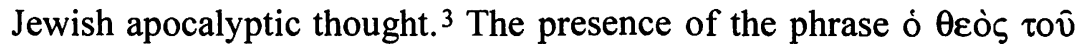

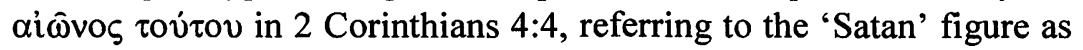
'the god of this age', alerts us to the significance of Jewish apocalypticism for interpreting a Pauline text that is intriguing in its own right and relevant for this discussion: 2 Corinthians 3:1-4:6.

J.C. Beker has stated the view that '[a]pocalyptic is not a peripheral curiosity for Paul but the central climate and focus of his thought, as it was for most Christian thinkers', and further that Paul's apocalypticism 'was not initiated by his conversion to Christ but formed the background of his Pharisaic world view' and that 'the apocalyptic structure of his thought remains the constant in his Pharisaic and Christian life'. ${ }^{4}$ Beker's thoroughgoing retrieval of Jewish apocalypticism as the indispensable framework for understanding the 'coherent centre' of Paul's thought is tempered at the same time by the recognition that in Paul there is genuine modification of apocalypticism: 'The reduction of apocalyptic terminology and the absence of apocalyptic speculation signifies that the Christ-event has strongly modified the dualistic structure of normal apocalyptic thought.' ${ }^{5}$ N.T. Wright also interprets Paul within a Jewish apocalyptic framework, albeit one considerably reworked both christologically and pneumatologically, ${ }^{6}$ and A.F. Segal and

2 See S.R. Garrett, 'The God of This World and the Affliction of Paul: 2 Cor 4:112', in Greeks, Romans, and Christians: Essays in Honour of Abraham J. Malherbe (eds. D.L. Balch, E. Ferguson and W.A. Meeks; Minneapolis, MN: Fortress Press, 1990), 104, who comments: '...the designation "god of this age" presupposes a dualistic frame of reference: this age (or this world) is implicitly contrasted with another' (emphases original); M.C. de Boer, 'Paul and Jewish Apocalyptic Eschatology', in Apocalyptic and the New Testament: Essays in Honour of J. Louis Martyn (JSNTSS 24; eds. J. Marcus and M.L. Soards; Sheffield: JSOT Press, 1989), 187, n. 17.

3 See, e.g., D.E. Aune, art. 'Apocalypticism', in Dictionary of Paul and His Letters [hereafter $D P L$ ] (eds. G.F. Hawthorne, R.P. Martin and D.G. Reid; Downers Grove, IL/Leicester: IVP, 1993), 30.

4 J.C. Beker, Paul the Apostle: The Triumph of God in Life and Thought (Edinburgh: T. \& T. Clark, 1989; orig. pub. Philadelphia/Edinburgh: Fortress Press/T. \& T. Clark, 1980), 144.

5 Beker, Paul the Apostle, 145.

6 In his essay 'Putting Paul Together Again: Toward a Synthesis of Pauline 
J.D.G. Dunn are further examples of recent interpreters who endorse the view that Jewish apocalypticism is central for interpreting Paul. 7 There are dissenting voices, however; E.P. Sanders, L.E. Keck and V.P. Branick are more sceptical about using an 'apocalyptic framework' for elucidating Paul's thought, pointing to differences as well as resemblances between Paul and Jewish apocalypticism. ${ }^{8}$ J.L. Martyn and R.G. Hall, on the other hand, defend the presence of apocalyptic thinking even in that most 'un-apocalyptic' Pauline letter, Galatians. ${ }^{9}$ My own view is that the framework of Jewish apocalypti-

Theology', in Pauline Theology Volume 1 (Minneapolis, MN: Fortress Press, 1991), 183-211, Wright declares: '... it is high time that, while affirming both that apocalyptic is the proper background for understanding Paul and that he retained the basic apocalyptic structure of thought even while modifying it consistently via his view of Christ and the Spirit, we released ourselves from the woodenly literal reading of apocalyptic language which has been such a strange characteristic of an otherwise linguistically sensitive age' (211). Although not his main point, Wright's commitment here to the centrality of 'apocalyptic' for interpreting Paul is clear.

7 See A.F. Segal, Paul the Convert: The Apostolate and Apostasy of Saul the Pharisee (New Haven: Yale University Press, 1990), 158-61, and J.D.G. Dunn, 'How New Was Paul's Gospel? The Problem of Continuity and Discontinuity', in Gospel in Paul: Studies on Corinthians, Galatians and Romans for Richard N. Longenecker (Sheffield: Sheffield Academic Press, 1994), 367-88, who writes: 'Not only is the centre of Paul's gospel apocalyptic in character, but its whole structure' (375), and further, '... hopefully the point is already clear and beyond dispute: that Paul's gospel was fundamentally shaped by an apocalyptic perspective, inevitably so, given the constitutive force of the resurrection and the outpoured Spirit in Christian self-understanding...' (377-78). However, Dunn also points to the need to understand not only the discontinuities between Paul's gospel and what went before in God's dealings with Israel (the 'apocalyptic perspective') but also the continuities (the 'heilsgeschichtlich perspective'); see pp. 378-87.

8 See E.P. Sanders, Paul and Palestinian Judaism: A Comparison of Patterns of Religion [hereafter PPJ (London: SCM Press Ltd., 1977), 543, 554-56, and idem, Paul (Past Masters; Oxford/New York: OUP, 1991), 34-39; L.E. Keck, 'Paul and Apocalyptic Theology', in Int 38 (1984), 229-41; V.P. Branick, 'Apocalyptic Paul?', in $C B Q 47$ (1985), 664-75. Rather surprisingly, Sanders (PPJ, 543) appears dismissive of apocalypticism: 'Since the conventions of apocalypticism had so little influence on him, the hypothesis might be put forward that before his conversion and call Paul was not especially apocalyptically oriented. This is one more reason for not supposing that Paul began with a set apocalyptic view and fitted Christ into it.'

9 See J.L. Martyn, 'Apocalyptic Antinomies in Paul's Letter to the Galatians', in NTS 31 (1985), 410-24, and R.G. Hall, 'Arguing Like an Apocalypse: Galatians and an Ancient Topos Outside the Graeco-Roman Rhetorical Tradition', in NTS 42 (1996), 434-53, respectively. The more recent article by Hall is particularly significant in that Hall argues that a 'juridical' argumentation drawn from Jewish apocalypticism is a framework better suited than the 'school tradition reflected in Graeco-Roman rhetorical handbooks' for understanding Paul's 'highly compressed arguments' in Galatians (see pp. 434-36). Interestingly, Hall looks to 1 Enoch (chs. 72-82 [the so-called 'Astronomical Book'] and chs. 85-90 [the so-called 'Animal Apocalypse']) and Jubilees (ch. 15) for the basis for an 'apocalyptic 
cism undeniably has genuine explanatory power for the interpretation of the Pauline letters, and that, specifically, it is highly significant for an analysis of Paul's explanations of the causes of Israel's unbelief; however, an over-reliance on such a framework may lead one to miss or ignore other influences upon Paul and so lead to distortion in interpreting his thought.

We turn now to a feature of Jewish apocalyptic thinking taken up by certain Jews (and, later, by Paul) to help explain Israel's partial obduracy towards God: the 'Satan' figure.

\section{III. 'Satan' as God's instrument / agent and Israel's partial obduracy}

A. The 'Satan' figure is not developed to any great degree in the canonical texts of the Hebrew Bible, with material of significance found only in Job 1-2, 1 Chronicles 21:1 and Zechariah 3:1-10. However, even with these texts there are problems in identifying (the) satan with the arch-enemy of God and his people of later Jewish and Christian traditions..$^{10}$ Despite the problems in ascertaining precise referents and in assigning dates, most scholars see a connection between (the) satan of these texts and the more developed 'Satan' figure (with various names) who opposes God and his people in several Jewish writings of the Second Temple period. P. Sacchi, in Jewish Apocalyptic and its History (Brescia, 1990 [ET 1996]), discusses the development of the concept of 'the devil' in Jewish traditions between $500 \mathrm{BCE}$ and $100 \mathrm{CE}$, distinguishing between traditions about rebel angels with a leader and the origin of evil on the one hand and traditions about an angel who accuses human beings of their misdeeds before God on the other." On the ambiguity of the

rhetoric' with which to understand Paul's arguments in Galatians (see esp. pp. 43639).

10 See H.I. Avalos, art. 'Satan', in The Oxford Companion to the Bible (eds. B.M. Metzger and M.D. Coogan; Oxford/New York: OUP, 1993), 678-79, who writes: 'In Job 1-2, the satan seems to be a legitimate member of God's council. In Zechariah 3.1-7 satan may refer to a member of God's council who objected to the appointment of Joshua as high priest. The mention of satan without the definite article in 1 Chronicles 21.1 has led some scholars to interpret it as a proper name, but one could also interpret it as "an adversary" or "an accuser" acting on God's behalf' (p. 679). See also E. Pagels, The Origin of Satan (London: Penguin Books, 1997; orig. pub. 1995 [US]/1996 [UK]), 39-44, who discusses these same three texts as well as the Balaam incident in Nu. 22:22-35 (all references to this work will be from the UK: 1997 Penguin Books edition).

"See Ch. 10, 'The Devil in Jewish Traditions of the Second Temple Period (c. 
'Satan' figure in the biblical texts and the eventual identification of 'the devil' (understood as the head of the fallen angels) with the accusing angel 'Satan', he writes:

[T] he figure of Satan is an ambiguous figure, because we do not fully understand what freedom of action he has within the heavenly court, and to what point he can harm humans and why. In this way Satan and the devil (whether Asa'el or Semeyaza) are drawing closer to each other. Within a short time their figures will converge completely, in the sense that Satan will become the name, or at least one of the names, of the devil. ${ }^{12}$

Sacchi also discusses the well known contradiction between 1 Chronicles 21:1 and 2 Samuel 24:1, viewing the latter as the source of the former, and explains the change in terms of the religious embarrassment felt by the Chronicler concerning the apparently capricious anger of God towards Israel and incitement of David to do wrong (as related in the 2 Samuel text), making the Chronicler resort to presenting the 'Satan' figure as the real causal agent of evil. ${ }^{13}$ What this biblical example may demonstrate, if 'Satan' is indeed a real name in the Chronicles text, is a refining of the idea of transcendent causality in Jewish thought, no longer solely attributing all events directly to God's ultimacy but allowing for transcendent secondary causes to explain the disturbing features of human existence in general and Israel's historical experience in particular. Along with Job 1-2, we may see in these examples from the Hebrew Bible the raw materials for a view of the 'Satan' figure as the executive instrument / agent of God's more disturbing purposes.

Concerning the concept of the 'Satan' figure in the Qumran literature and the traditions about 'Beliar' in the intertestamental period, it will not be necessary to expand upon them here since these are themes which often appear in the work of biblical and Dead Sea Scrolls scholars. What is important to bear in mind for our present purpose is that there was development of several traditions concerning

500 BCE-100 CE)', in Sacchi, Jewish Apocalyptic and its History, 211-32, first presented as a paper at the International Congress on the Devil at Turin in October 1988. Sacchi examines and compares both canonical and non-canonical texts, including in his review 1 Enoch, Ezekiel, Second Isaiah, Zechariah, Job, 1 Chronicles, 2 Samuel, Sirach, Jubilees, 1QS, 1QH, Wisdom, the Testaments of the Twelve Patriarchs, the Testament of Job, and (very briefly, and only for the sake of completeness) the New Testament. He concludes with philosophical observations on the nature of evil and its opposition to ordered being (see pp. 231-32).

12 Sacchi, Jewish Apocalyptic and its History, 223.

13 See Sacchi, Jewish Apocalyptic and its History, 222-23. For a more 'political' explanation of the Chronicler's alteration of the story, see Pagels, The Origin of Satan, 42-43. 
evil angelic beings, their activity and the origin of evil in the Second Temple period (with as yet imprecise understanding of the nature and extent of the influence of Iranian dualism), ${ }^{14}$ but that by the time of Paul the concept of an evil angelic being who opposed God and his people at his own initiative and yet whose activity was clearly not 'outside' the purposes of God (and indeed who could be viewed at times as his executive instrument / agent) was firmly established in Jewish thought. In the first-century BCE / CE text known as the Testament of Job, for example, 15 Satan (or 'the devil', in this text) needs authorisation from God to do his destructive work (cf. TJob 8:1$3 ; 16: 1-4 ; 20: 1-3$ ), but, as Sacchi observes, he '...becomes in some way God's instrument and collaborator, somewhat like the satan in the canonical book of Job'. ${ }^{16}$ Sacchi goes on to say:

Ancient Hebrew religion did not hesitate to attribute any misfortune to God. Now the preference turns to a formula of 'diabolical initiative and divine authorization'. The two figures, God and the devil, draw strangely closer: the devil must converse with God if he wishes to carry out certain plans of his. ${ }^{17}$

A 'harmonisation' of divine and satanic causal agencies was a possible solution for Jewish thinkers in Paul's day faced with the problem of how to relate satisfactorily the problem of evil with the divine realm. What needs further attention now for the purpose of comparison with Paul, and which is conceivably as much a sociological as a theological issue, ${ }^{18}$ is the connection made at times by Jewish writers of the Second Temple period between the activity of the 'Satan' figure and Israel's spiritual obduracy.

B. There is evidence in the Hebrew Bible and Jewish intertestamental literature that Israel understood itself to be under the special protection and guidance of Yahweh (or his angelic representative

14 As, for example, both Sacchi and Collins admit; see Sacchi, Jewish Apocalyptic and its History, 221, and Collins, Apocalypticism, 41-43 (who discusses possible 'Zoroastrian influence' on 1QS 3:13-4:26), respectively.

15 On questions concerning the dating and provenance of this text and other related issues, see R.P. Spittler, 'Testament of Job: A New Translation and Introduction', in The Old Testament Pseudepigrapha Vol. I [hereafter OTP Vol. I; similarly, OTP Vol. II] (ed. J.H. Charlesworth; New York: Doubleday, 1983), 82968, esp. Introduction, 829-37. See also Garrett, 'The God of this World', 106 and n. 35 .

16 Sacchi, Jewish Apocalyptic and its History, 230.

17 Sacchi, Jewish Apocalyptic and its History, 230.

18 Pagels, in The Origin of Satan, Ch. II 'The Social History of Satan: From the Hebrew Bible to the Gospels', 35-62, focuses on the sociological aspect of the use of the 'Satan' figure in Jewish sectarian thought. See further my comments about Pagels in section III.B., below. 
Michael) while pagan nations were seen as being under the influence of angels / spirits that led them astray (cf. Dt. 32:8f. [LXX];19 $1 \mathrm{Ch}$. 16:26 [LXX];20 Dn. 10:20f.; Sir. 17:17; Jub. 15:30-32). However, contrary to such a (majority) view within the Jewish tradition, there is also evidence from other texts which shows that some authors were able to conceive of a certain causal link between part of Israel going astray and the activity of the 'Satan' figure (albeit still within the overall purposes of God), as the following texts illustrate:

During all those years Belial shall be unleashed against Israel, as He spoke by the hand of Isaiah, son of Amoz, saying, Terror and the pit and the snare are upon you, $O$ inhabitant of the land (Is. xxiv, 17). Interpreted, these are the three nets of Belial with which Levi son of Jacob said that he catches Israel by setting them up as three kinds of righteousness. The first is fornication, the second is riches, and the third is profanation of the Temple. Whoever escapes the first is caught in the second, and whoever saves himself from the second is caught in the third (Is. xxiv, 18). (CD 4:12-19) ${ }^{21}$

.... and the dominion of Belial will be on them to hand them over to the sword for a week of yea[rs...And in] that jubilee, they will break all My precepts and all My commandments which I will have commanded th[em...by the hand of] My servants the prophets, [and they will...] to contend one with another for seventy years from the day of breaking the [Law and the] Covenant which they will break. I will give them [into the hand of the an]gels of Persecution, and they will rule over them, and they will not know and understand that I am furious with them because of their transgressions...(4Q390 Fr. 2 1:3-7) 22

And it came about that after Hezekiah had died, and Manasseh had become king, (Manasseh) did not remember the commands of Hezekiah his father, but forgot them; and Sammael dwelt in Manasseh and clung closely to him. And Manasseh abandoned the service of the LORD of his father, and he served Satan, and his angels, and his powers. And he turned his father's

19 In Dt. 32:8, LXX and a Qumran Ms have 'the gods' compared with MT's 'the sons of Israel/Israelites'. On this verse, see G. von Rad, Deuteronomy: $A$ Commentary (ET; London: SCM Press Ltd., 1966; orig. pub. Göttingen: 1964), 196-97, and n. 2 for textual details. Von Rad writes: 'At that time, that is, at the beginning of all history, when Yahweh was fixing the boundaries of all peoples, he divided up the nations according to the number of the sons of God; i.e. he subordinated one nation to each of the heavenly beings who had to take care of it, like a guardian angel. He departed from this general arrangement in one case alone: Israel was chosen by Yahweh for himself and subordinated directly to himself (196-97).

201 Ch. 16:26 (NRSV): 'For all the gods of the peoples are idols [LXX: $\delta \alpha i \mu \omega v \varepsilon \varsigma$ $=$ 'demons'], but the LORD made the heavens'.

21 G. Vermes, The Complete Dead Sea Scrolls in English (London: Penguin Books, 1998), 130.

22 Vermes, The Complete Dead Sea Scrolls in English, 544. Two large fragments of this text (also known as Pseudo-Moses, and assigned a second-century BCE date by D. Dimant) form the basis of Vermes's translation (CDSSE, 543-44). 
house, which had been in the presence of Hezekiah, away [from] the words of wisdom and the service of the LORD. Manasseh turned them away so that they served Beliar; for the angel of iniquity who rules this world is Beliar, whose name is Matanbukus. And he rejoiced over Jerusalem because of Manasseh, [and he strengthened him] in causing apostasy, and in the iniquity which was disseminated in Jerusalem. (Ascension of Isaiah 2:1-4) ${ }^{23}$

The clearest set of examples of a causal link between the 'Satan' figure and Israel's spiritual obduracy in Jewish thought comes from the sectarian writings of Qumran, where the view that all those in Israel who have not 'volunteered' for the Community are in reality under the dominion of Belial, is much in evidence. E. Pagels, in her book The Origin of Satan (New York: 1995), draws out particularly clearly the connection between the Jewish sectarian need to characterise other Jews with whom one differed as opponents and the attribution to the 'Satan' figure of the inspirational energy behind such 'deviance' ${ }^{24}$ Concerning the Essenes at Qumran, she writes:

These devout and passionate sectarians saw the foreign occupation of Palestine - and the accommodation of the majority of Jews to that occupation-as evidence that the forces of evil had taken over the world and-in the form of Satan, Mastema, or the Prince of Darkness-infiltrated and taken over God's own people, turning most of them into allies of the Evil One. ${ }^{25}$

The idea that 'unbelievers', whether pagan nations or unfaithful Israelites, were under the influence of 'Satan' while remaining within the mysterious purposes of God, was evidently one not original to Paul. He, like other Jews before him, would also 'demonise' fellowJews with whom he disagreed, although exegesis of relevant texts leads me to the view that this was more than mere rhetorical posturing on Paul's part.

\section{Paul's views in 2 Corinthians 3-4 and affinity with Romans 9-11}

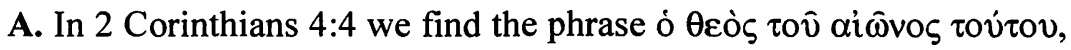
which, along with the majority of interpreters, I take to be a reference to 'Satan'. The activity of this figure, who 'blinded the minds of

23 M.A. Knibb, 'Martyrdom and Ascension of Isaiah: A New Translation and Introduction', in OTP Vol. II (ed. J.H. Charlesworth, 1985), 157-58. I am indebted to Prof. M.M.B. Turner of the London Bible College for drawing my attention to this part of the text of the Ascension, as well as to 4Q390.

24 See Pagels, The Origin of Satan (London: 1997 edition), 35-62, esp. pp. 43-62.

25 Pagels, The Origin of Satan, 57. 


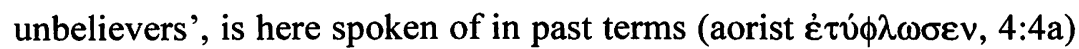
because Paul sees this figure as the cause of the lack of positive response to his gospel on the part of those who heard it and yet did not believe, i.e. 'the unbelievers' (4:4a). The aim of 'the god of this age' is to prevent the spiritual illumination which alone comes through the

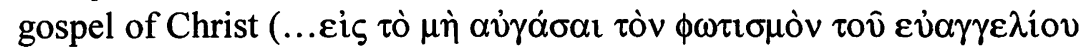

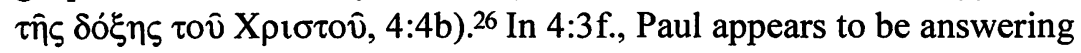
the charge that his gospel is 'veiled' by admitting that, indeed, it is veiled, but only to 'those who are perishing', 'among whom' Satan is doing his work. There is no reason to believe that the category 'unbelievers' excludes Jewish unbelievers, and every reason to suppose (from Paul's foregoing discussion) that they are included.27 Moreover, the presumed charge (and admission) in 4:3 that Paul's gospel is 'veiled' immediately brings to mind his statements just a few sentences back about 'the veil' that lies over 'the heart' of those Jews contemporary with Paul who hear 'the old covenant / Moses' read to them (3:14f.). Not only is Paul's gospel 'veiled' to Jewish unbelievers but also their own scriptures. Spiritual obtuseness to the message about the Messiah Jesus is matched by spiritual obtuseness to the Torah itself. But, we need to ask ourselves, is the cause the same in both cases?

In the one case - that of spiritual obtuseness to the message about the Messiah-it is clear that the 'god of this age', i.e. the 'Satan' figure, is the attributed causal agent of unbelief. However, in the other case, it would be hard not to see allusion to Isaiah 6:9f. and 29:10ff. in Paul's words in $3: 14 \mathrm{a}$, via the 'hook-word' $\dot{\varepsilon} \pi \omega \rho \omega \theta \eta$, (cf. Rom. 11:7f.). If that is so, then Paul is suggesting in 3:14f. that God is the causal agent behind Israel's spiritual stupor, as in fact he does argue a short time later in Romans 11 , even if from quite a different perspective. One may therefore argue for theological coherence between 2 Corinthians 3 and Romans 9-11 in the matter of Paul's statements concerning Israel's unbelief on the basis that both passages speak of a spiritual obduracy on the part of Jews, the cause of which is God himself. But can one legitimately speak of coherence between 2

\footnotetext{
26 It is also possible that $\varepsilon i \varsigma$ tó is consecutive: 'with the result that'; see V.P. Furnish, II Corinthians (AB 32A; Garden City, NY: Doubleday \& Company, Inc., 1984), 221.

27 Garrett, however, believes that the referent of 'unbelievers' in $4: 4 \mathrm{a}$ is not the unconverted in general but the specific group of Paul's opponents in Corinth ('The God of this World', 101-102 and ns. 12 and 13). In my view, the identical phrases

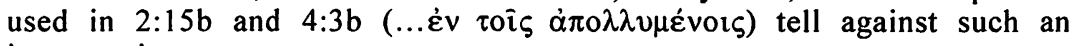
interpretation.
} 
Corinthians 4:4 and Romans 9-11-or, for that matter, of internal coherence within 2 Corinthians 3-4 itself-when 2 Corinthians 4:4 attributes to Satan the cause of Jewish (and Gentile) unbelief, while Romans 11 attributes to God the cause of Israel's 'hardening' (and hence unbelief) with respect to the gospel?

With reference to the 'Satan' figure in the rest of the Corinthian correspondence, we observe that in 2 Corinthians 12:1-10 there is an example of Paul understanding something essentially evil-'a

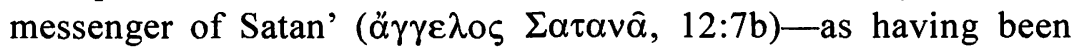
'given' him by God with a presumed good purpose in mind ('in order that I might not be puffed up with pride', $12: 7 \mathrm{a}, \mathrm{b}$ [my translation]). This is a clear instance of Paul viewing the 'Satan' figure as an executive instrument / agent in God's purposes. Further, in 1 Corinthians 5:5, it may be observed that the 'handing over' of the incestuous man to Satan implies that Paul viewed Satan at one and the same time as the opponent of the Christian community and as the agent of God in bringing about a corrective discipline leading to 'salvation'. Paul's dualistic view of humanity, in line with Jewish apocalypticism in general, saw people as being either in God's camp or in Satan's; this dualistic view is tempered, however, both in Paul and in Jewish apocalypticism, by a strong sense of God's ultimacy. Satan is an active, deceptive and powerful being opposed to God and his people, ${ }^{28}$ but God overrides Satan's purposes and activities with

28 It is evident, however, that Paul's use of the 'Satan' figure to express his understanding of 'active' evil was not the only possibility available to him. While, for example, the 'Satan' figure appears frequently in 2 Corinthians (six occurrences: $2: 11 ; 4: 4 ; 6: 15 ; 11: 3,14 ; 12: 7)$, references to this figure in Romans are conspicuous for their absence (only one specific mention in 16:20a, and occurring in a slightly abrupt admonitory section [16:17-20] interrupting the flow of personal greetings that makes up most of Rom. 16). In Romans, written shortly after 2 Corinthians, Paul does not employ the 'Satan' figure as a personalised focus of evil so much as the more abstract (or even 'demythologized' [Dunn, Romans 916 (Dallas: Word, 1988), 905]) figures of Sin and Death. Furthermore, he speaks of 'powers' of various kinds - in Romans and in other letters-to express what he considers to be unseen evil realities from which the gospel delivers believers (e.g. Rom. 8:38f.; 1 Cor. 15:24; Gal. 4:3, 9; cf. Col. 1:16; 2:8, 20; Eph. 1:21). R. Yates, in his article 'The Powers of Evil in the New Testament' (EvQ 52 [1980], 97-111), comments on the 'principalities and powers' in the Pauline corpus: 'It is our contention that these form an alternative collective concept for the powers of evil to that of Satan. But they are not mutually exclusive;...' (102-103); unfortunately, Yates does not attempt to suggest what the connections might be. Two other

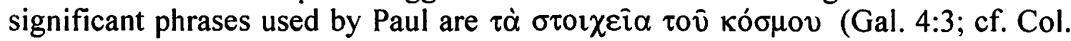

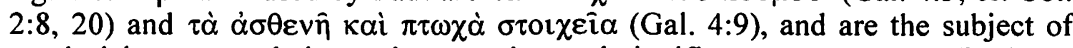
much debate as to their precise meaning and significance; see, e.g., H.D. Betz, Galatians: A Commentary on Paul's Letter to the Churches in Galatia (Hermeneia; Philadelphia: Fortress Press, 1979), 204-205, 215-17; F.F. Bruce, The 
his own purpose and activity. ${ }^{29}$ Paul's statements about Satan's role in 2 Corinthians 12 and 1 Corinthians 5 help one to see that it may not be such a contradiction as at first appears to be the case to attribute Israel's unbelief causally both to God and to Satan. For Paul, Satan's activities do not escape the parameters of God's logically prior freedom to do as he pleases and effectuate his purposes, even in the area of human belief. Second Corinthians 3-4 can thus be viewed as internally coherent on the subject of Israel's unbelief, and similarly 2 Corinthians $4: 4$ as theologically compatible with Romans 11 . But, the question may be pressed, are Paul's explanations of the causes of Israel's unbelief in 2 Corinthians 3:1-4:6 entirely consonant with Romans 9-11? Both texts affirm suprahistorical causal agents behind Israel's unbelief, viz. God and Satan in the case of 2 Corinthians, God alone in the case of Romans. However, Romans 9-11, differently from 2 Corinthians 3-4, also focuses on a human causal agent: unbelieving Israel itself. This presents a further challenge to the view that Paul's statements on the causes of Israel's unbelief are entirely reconcilable with one another.

B. It may be possible to account for the different angles on Jewish unbelief which Paul brings to his arguments in 2 Corinthians 3-4 and Romans 9-11 by recourse to M.C. de Boer's analysis of two main tendencies (or 'tracks', to use his terminology) in Jewish

Epistle to the Galatians: A Commentary on the Greek Text (NIGTC; Exeter: The Paternoster Press, 1982), 193-94, 202-205; J.D.G. Dunn, The Epistle to the Galatians (BNTC; London: A. \& C. Black, 1993), 212-13, 225-27, and idem, The Epistles to the Colossians and to Philemon (NIGTC; Grand Rapids, Michigan/Carlisle: Eerdmans/Paternoster Press, 1996), 146-51, 188-90; G.W. Hansen, Galatians (IVPNTCS 9; Downers Grove, IL/Leicester: IVP, 1994), $114-$ 16, 127-29; D. Lührmann, Galatians: A Continental Commentary (ET, by O.C. Dean, Jr.; Minneapolis: Fortress Press, 1992; orig. pub. Zürich, 1978), 80, 82-85; D.G. Reid, art. 'Elements/Elemental Spirits of the World', in DPL (1993), 229-33. L. Gaston reads Galatians 3-4 in such a way as to deny that Paul ever intended to equate Jewish existence under the Sinai covenant with pagan enslavement to 'nogods'; see his Paul and the Torah (Vancouver: University of British Colombia Press, 1987), Ch. 2 'Angels and Gentiles in Early Judaism and in Paul', 35-44, esp. pp. 42-44. C.E. Arnold, however, has recently reaffirmed the view that Paul equates $\tau \dot{\alpha} \sigma \tau 0 \iota \chi \varepsilon i \hat{\alpha}$ with evil angels/spirits who not only adversely affect the life of Gentiles but also Jews 'under Torah', the connection being that both groups are part of the 'present evil age' (cf. Gal. 1:4) under the control of 'Satan' (cf. 2 Cor. 4:4), a condition from which both groups can only be freed by faith in Christ; see his article 'Returning to the Domain of the Powers: STOICHEIA as Evil Spirits in Galatians 4:3, 9', in NovT 38-1 (1996), 55-76, esp. pp. 67-70, 75-76.

29 See the comments by D.E. Aune, art. 'Apocalypticism', in DPL, 28, and J.J. Collins, 'Dualism in a Jewish Context', in Apocalypticism, 43-45. 
apocalypticism, which he expounds in his essay 'Paul and Jewish Apocalyptic Eschatology' (Apocalyptic and the New Testament [Sheffield: 1989], pp. 169-90). He designates these two distinct strands within Jewish apocalypticism 'cosmological-apocalyptic eschatology' and 'forensic-apocalyptic eschatology', respectively. 30 De Boer's analysis provides a better focus for the task of comparing Paul with Jewish apocalypticism than is usually the case when the latter is treated with little consideration for varying emphases in the literature. For the purpose of clarity, the following is a summary of de Boer's two 'tracks': 31

The basic features of the 'cosmological' tendency include a world currently under the dominion of evil angelic powers, a righteous remnant chosen by God who submit to the Creator (the God of Israel) and a future decisive intervention by God who will overthrow the evil powers, deliver the righteous and establish the new age in which he will reign unopposed [track 1]; the basic features of the 'forensic' tendency include an absence or even rejection of evil cosmological forces, an emphasis on free will and decision, the gracious provision of the Law as a remedy for the sinful disposition in people to reject or disobey God, and a Final Judgement issuing in reward or punishment based on the criterion of a person's stance in this life vis-à-vis the Law [track 2].

It is evident that these two tendencies in Jewish apocalypticism resonate at distinct points with both Paul's letters and the literature of Qumran. ${ }^{32}$ De Boer focuses on two texts-1 Enoch 1-36 (the 'Book of the Watchers') and 2 Baruch - which, according to him, respectively exemplify the cosmological and forensic tendencies in almost 'pure' form. ${ }^{33}$ The dating of 1 Enoch $1-36$ (itself composite) ${ }^{34}$ is problematic, but Sacchi's dating (expressed in the view that it 'remains the only source before $200 \mathrm{BCE}$ useful for understanding apocalyptic thought' $)^{35}$ is supported by the fact that the text undoubtedly was known to the sectarians at Qumran, given the discovery there of Aramaic fragments of this and other parts of the Enochic 'Pentateuch'. ${ }^{36}$ The date of 2 Baruch is generally agreed to be

30 See de Boer, 'Paul', 169-76.

31 For de Boer's fuller definitions on which my summary is based, see 'Paul', 18081.

32 Regarding the literature of Qumran, de Boer ('Paul', 177) points out that both 'tracks' are to be found in the Dead Sea Scrolls, mentioning 1QS 1-4, 1QM and $\mathrm{CD}$ in particular.

33 See de Boer, 'Paul', 176.

34 See Sacchi, Jewish Apocalyptic and Its History, 95-104, 108.

35 Sacchi, Jewish Apocalyptic and Its History, 92.

36 In addition to Sacchi on issues of dating, see de Boer, 'Paul', 188 and n. 22, and

E. Isaac, '1 (Ethiopic Apocalypse of) Enoch: A New Translation and Introduction', 
between 100 and $120 \mathrm{CE}$ (cf. 4 Ezra, dated at about $100 \mathrm{CE}$, with which 2 Baruch has affinities). ${ }^{37}$ De Boer also makes the point that 'the evidence indicates that track 2 [forensic] overtook and displaced track 1 [cosmological] completely after the disaster of $70 \mathrm{CE}$ (cf. 4 Ezra, 2 Baruch)' .38

The significance of this for understanding Paul's statements about Jewish unbelief in 2 Corinthians 3-4 and Romans 9-11 now becomes clear, although de Boer does not specifically deal with these texts in his essay. ${ }^{39}$ Paul wrote all his letters prior to the crisis of the destruction of the Temple and during a period when both tendencies co-existed in Jewish thinking about the End, as de Boer points out. 40 The two-age framework and references to Satan as both instrument / agent of God and adversary who opposes God, his people and appointed emissaries such as Paul, which we find in 2 Corinthians, clearly are evidence of the cosmological tendency in Paul's thinking. Although this tendency is also evident in Romans (in chapters 6-8, especially), there is another emphasis in other parts of Romans more redolent of the forensic tendency, but with both tendencies, as one would expect, christologically modified. ${ }^{41}$ In Romans 9-11 the two 'tracks' are both present: the 'elect remnant' motif from the first track, and the focus on Israel's culpable unbelief and wrong position as regards the Law from the second track. This is why Paul can attribute the cause of Israel's unbelief to God (unbelieving Israel is not the elect remnant; track 1) and to Israel herself (the Law is no longer the remedy for sin nor the criterion for acquittal at the Last Judgement because the Messiah has now come, but Israel has chosen freely and wilfully to reject God's way; track 2).

in OTP Vol. I (ed. J.H. Charlesworth), 6-8.

37 See, e.g., de Boer, 'Paul', 178; A.F.J. Klijn, '2 (Syriac Apocalypse of) Baruch: A New Translation and Introduction', in OTP Vol. I (ed. J.H. Charlesworth), 61617; Sacchi, Jewish Apocalyptic and Its History, 122 and n. 12.

38 De Boer, 'Paul', 182. In the case of 4 Ezra, however, M.E. Stone analyses its author's seemingly ambiguous statements about 'the End' and concludes that different 'associational complexes' of eschatological ideas (cf. de Boer's two 'tracks') are brought together by the author, albeit with a clear preponderance of 'associational complexes' to do with 'the fate or suffering of Israel' over that to do with 'universal eschatology' or the 'problem of man'; see his article 'Coherence and Inconsistency in the Apocalypses: The Case of 'The End' in 4 Ezra', in JBL 102/2 (1983), 229-43, esp. pp. 235-38, 241-43.

39 For de Boer's application of his analysis to Paul's writings, see 'Paul', 182-85.

40 De Boer, 'Paul', 182.

41 For de Boer's comments about Romans, see 'Paul', 182-84. However, de Boer restricts his comments almost entirely to Rom. 1-8 and does not apply his analysis to Rom. 9-11. 
In 2 Corinthians 3-4, however, Paul attributes the cause of Israel's unbelief to God (obliquely) and to Satan (directly), but with both arguments following track 1 (God is sovereign and [implicitly] 'hardens' non-elect Jews [and elect Jews who have not yet evidenced faith], whose understanding is 'veiled' and who are simultaneously 'blinded' by Satan). The two 'tracks' thus co-exist in Paul, reflecting his indebtedness to the Judaism(s) of his own time, and yet are reworked around the new centre of Paul's life and thought-his experiential knowledge of Jesus as the Messiah raised by God from death-to serve new arguments intended to instruct and encourage the congregations of Christian believers in Corinth and Rome.

\section{Concluding remarks}

Jewish apocalypticism helps one to understand the forms of argument that Paul employs to express his understanding of the diverse causes behind the widespread Jewish refusal of the gospel that he and his colleagues preached. Paul's affirmations in 2 Corinthians 3-4 and Romans 9-11 (and even in 1 Thessalonians 2:14-16) regarding the causes of Jewish 'unbelief' - the stubbornness of the human heart, the malevolent intentions and actions of the 'Satan' figure and, above all, the ultimacy and mystery of the purposeful will and activity of Israel's God-are dependent on ways of thinking characteristic of some Jews in the Second Temple period, and so the theological coherence or otherwise of those affirmations cannot be fairly assessed without recourse to that intellectual matrix.

This, however, does not necessarily resolve all the questions about 'coherence' relating to Paul's views on Israel. The fact that we can locate Paul's statements about the causes of Jewish unbelief in their appropriate historical and intellectual context may, it could be argued, demonstrate nothing more than that Paul was heir to traditions which were presumably 'coherent' to him and to (some) audiences in his own day. However, the real question for audiences today, schooled in a very different understanding of causality, is whether Paul's statements about Israel's unbelief can be viewed as 'coherent' by $u s$, or whether we cannot but read him as being at best 'paradoxical', at worst 'confused'. Two points in response can be made at this juncture: (1) the consistency of Paul's arguments about God's faithfulness to Israel in Romans 9-11 and the compatibility of views between that text and 2 Corinthians 3-4, which close exegesis helps to demonstrate, 
convince me that Paul was a careful thinker; ${ }^{42}$ and (2) modern criteria of rational discourse and 'coherence' are as culture-specific as those of first-century Jews and Christians, and therefore should not be regarded as absolute for evaluating the supposed 'coherence' (or lack thereof) of other culturally specific modes of discourse, even though we cannot entirely escape formulating questions about coherence in terms deriving from our intellectual matrix.

Although the focus of my concerns in this article is the question of coherence with regard to a particular theme in Paul's thinking and not the whole, the wider question of Paul's overall theological coherence inevitably looms in such an enquiry as this. That said, I believe that a demonstration of arboreal competence in the case of a few of Paul's trees argues in favour of a rather nice wood overall.

42 Penetrating discussion of Paul included in a recent work by D.A. Templeton (The New Testament as True Fiction [Sheffield: Sheffield Academic Press, 1999]) reflects his conviction that the dimension of poetic imagination must not be neglected in our interpretation of the apostle's writings (see in particular Ch. 8 'Through a Glass Brightly: The Magic of Metaphor [Paul Apostle and Genius: 2 Corinthians 3.18]', 184-209). While I certainly do not disagree with that perspective, it remains important to maintain that careful reasoning may as much be a feature of Paul's writings to take into account as poetic / 'apocalyptic' imagination for interpreters to do justice to Paul. 